рака является инфекция, сопровождающая всегда рак пейки и часто ведущя после облучения г воспалительным процессам, перитониту и сепсису. Јеченде радием может быть или кратким с большими дозами, или же на протяжения пятщ дней малыми дозами. Радий может быть применим только до операции удаленвя матки, ввиду того, что после экстирпации возможно образование ректального вагинального свищей. Радий является местной терапией, хотя G. применяет д терапию на расстоянии (Radiumfernetherapie), которая подобно лучам Рентпена, действует в глубину. Јечение Р е н т е н м после короткого облучения радиез не действительн. При метастазах применяются всключительно лучи Рентгена. В зависимости от показаний к той или иной терашии, автор делит рак шейлд на 4 группы: 1) Начальная стадия-поражен ограниченный участок; подлежит операции; 2) рак начинает перехоцить границы пейки, матка подвижна-на границе операбильности; 3) поражена тазовая клетчатка с одной или обоих сторон-слғчащ нө операбильные; 4) метастазы в соседних органах-случаи не поддаются ниталому лечению. K первой группе случаев Gun sett относит кроме того еще рагд при беременности, раки, осложненные старым воспалительным процессом, и случал резистентные в отношении радия.

M. I.

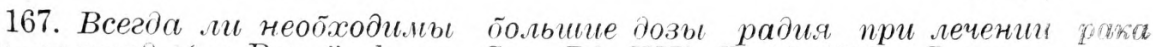
шейки матки? (по Ber. ii. d. ges. Gyn. Bd. XIV, H. 11, 1928). B то времд общее направление во Франции применять при лечении рака лучами радия очень высокие дозы (школа $\mathrm{R}$ eg a u д доводит дозы до 9000 milligr.-Element. часов), Degrais, первый применивпий во Франции лучи радия в 1908 году, лелдтся некоторыми своими случаями, в которых рак шейки установлен клинически п्ञ гистологически, где автор применял минимальные дозы радия с хоропим успехом, напр., случай, имевший место в 1926 гогу. Больная, получив 360 milligr.-Elementчасов., от дальнейшего лечения отказалась и, несмотря на это, до сих пор ғчднячески здорова. Эти наблюдения заставляют автора высказать сомнение, деиствительно ли сущность лечения рака лучали радия заключается во все возраетающих дозах. M. ЦL.

168. Ранняя диагностика рака иейки матки может быть обнаруғева по мнению H e i d l e r’a (Wien. klin. Woch. № 24, 1928) кольпоскопом H inselmann’a. Соскоб открытых беловатых мест и их гистологическое исследованпеобеспечивает раннюю диагностику. Leukoplakia, по мнению автора, есть истдннал картина начальной формы рака пейки матки. До сего времени неизвестно в лщтературе ни одного случая leukoplaki'n, из которой рано или поздно не образовалось бы рака.

M. Дьюсно.

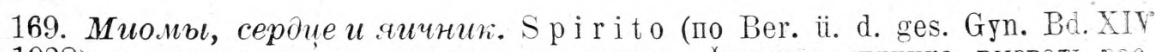
Н.11. 1928), желая выяснить, может ли измененная функция яичника, вызвать расстройства деятельности матки, сердца и желез внутренней секреции (надпочечник. щитовидная железа) и кроме того, может ли миома, как таковая, вызвать те-же расстройства в вышеназванных органах. Пля этой цели автор изготовил четыре различных экстракта из нормальной маточной стенки, миомы, нормального яичника. и яичника женщины с миомой. Впрыскивая морским свинкам внутрибртштнно 1-3 кб. см. вщродолжение 4-х месяцев, автор установил, что овариальный әғстракт всегда имеет влияние на матку и вызывает в ней состояние близкое т течке. Экстракты маточной мускулатуры и миомы никакого влияния на матку не оказывают; кроме того ни один из әкстрактов не вызвал и в надпочечнике каких-лдбо изменений. Иначе реагирует щитовидная железа на введение экстрактов, особенно полученного из миомы. Автор всегда находил гиперфункцию как в смысле гистологическом, так и функциональном. S. объясняет эти изменения защитной реакцией организма на токсическое цействие экстракта миомы. Влияние экстрактов на сердечно-сосудистую систему выражается только в незначительном падении кровяного давления,-макро и микроскопических изменений не наблюдается. S. прксоединяется к мнению M irto, D e c i 0 и др., что токсичность миомы зависит от самой субстанции миомы и этой именно токсичностью объясняет нарушение сердечно деятельности и изменения кровяного давления при миомах. М. Дыхно.

170. Местная вакиинотерапия при гоноррее у эсеншин. A i toff (La: presse med., № 77, 1928 г.) применил гонококковый антивирус по Б е з р д де прд различных формах женской гонорреи. Антивирус находился в соприкосновенуи со сдизистой втечение 2-4 дней, затем наступал отдых, во время которого провзво- 
дильсь обильные промывания. Под наблодением автора было 26 больных, причем пзлечение наступило в 16 случаях, улучпение в 6 , а в 4 случаях отмечено ухупенпе.

A. LL.йmpueb.

\section{ж) Невропатология.}

171. Prof. R o th fel d описывает случай afgermuвной потери тонуса при c.vere u mpu opaasue (Gelo-und Orgasmolepsia) (Zeitschr. f. d. g. N. u. P. Bd 115. 1928 г.) у мужчины 39 ґ., причем иногда эти состояния сонровождаются мимолетной потерей сознания $(1-2$ сек.). Припадков сна нигогда не отмечалось. Б-ой много курил, иногда выпивал; никотин и алкоголизм благоприятствовали наступлению прнпадков. Псследование внутрен. орг., неврологическое, глазное дно, $\mathrm{RW-}$ да.ло отрицательные результаты; рентгенограмма черепа тоже без особенностей. ІІсследование вегетативной н. системы указывало на умеренную ваготонию. Наличие одновременной аффективной потери тонуса и сознания при смехе отличает данный случай от нарғолепсии. В данном заболевании, по мнению автора, играет роль недостаточность центральной нервной системы, в особенности суббортикальных ганглй. Тагое наблюдение раньпе (в 1902 г.) описал 0 p p e $n$ h e im и с неготорой вероятностью сюда может быть отнесен случай Ferriri; других случаев в .итературе не описано.

С. Эсселевич.

172. Ф п л и м о н о в в статье „К вопросу о клиниеских методах измерения mонуса" (Zeitschr. f. d. g. N. u. P. Bd. 115, 1928 г.) подчеркивает положительные и отрицательные стороны метода Rieger-Spjegcl's и своего (предложенного им в Zeitsch. f. d. g. N. u. P. Bd. 96. H. 1-2); отмечает, что оба метода пиетот дело с принцилиально различными клиническими феноменами и один изних не может быть ваменен другим. А. констатирует, что метод Spiegel'я дает «превосходную тартину «der plastischen Hурегtonie», метод же автора регистрирует пасспвные движения, как непрерывный процесс, благодаря чему возможно исследовать всю клиническую картину гипертоний, а особенно Py-Hypertonie, со всеми ее атрибутами. Задачу своего метода автор формулирует следующим образом: 1) Tar называемые «Ру-Hуреrtonie» или, что тоже, „spastische Hypertonie“ характеризуются «stossartige» явлениями 2) вопрос о том: следует ли причислять әти .stossartigen“ явления $\mathrm{i}$ понятию о тонусе или нет, имеет совершенно условное значение; важно только, что эти явления имегот большое значение; 3) изучение этих явлений возможно только методом, регистрирующим пассивные движения как один непрерывный процесс.

С. Эсселевич.

173. С агр делает попыту на основании двух случаев объяснить психогенез mолонорического си.иmmonoromnлenca (Zeitschr. f. d. g. N. u. Ps. Bd. 115, 28 г.). Некоторые авторы рассматривали ипохондрический симпт., как выявление неврастении пли же выражение другой болезненной формы (Kraepelin, Bleuler, Wollenberg, T u ezek и др.); другие же рассматривали как самостоятельную картину болезни (Som mer, Bo e ttiger, R a e ck e и др.). Schüle причиной считает гиперстезию чувствительных нервов в определенных областях. Freud и Ferenczi считают, что происходит „генитализация ипохондрически рассматриваемого органа, вследствие сдвига либидо из генитальной сферы на определенный орган“. Вследствие психотравматического переживания ощущений, libido накапливается на определенном месте организма в связи с чрезмерной концентращией внимания на этом месте. „Эта гипотеза, как отражающая современные психологические воззрения приближает к более глубокому пониманию психогенеза ипохондрий“, говорит автор, переходя г своим случаям. В случае А, б-ой 28 лет, страдает последние 10 лет «неврастенически-ипохондрически окрапенным симптгомплексом с состояниями страха и делерсонализации личности». Своеобразные жа.Іобы б-ого-(„толстеет и распухает спина.... появляется чувство жара... чувство увеличения головы и спины... все тело во мне напрягается.... если выходит слизь со стулові, с мочей... тогда наступает приятное чувство усталости... когда все напрягается, тогда мне кажется все чуждым.... бывает чувство страха“)-автор сравнивает с геми, которыми сопровождается генитальная эрекция. Деперсонализация высгупает в особенности на высоте кульминационного пункта. Б ой страдал частыми поллюиями и считал себя «психическим импотентом». Комплекс импотенции по мнению автора обязан своим происхождением „Kastrationskomplex", происходящему из инфантильой психико-сексуальной организации субъекта. 'В случае Б, б-ой 42 лет, болен два года, заболел после супружеской неверности, стал и имптентом, „одновременно выступили неланхолический симпомокомплекс и ипохон- 